\title{
Harmonia axyridis Pallas (Coleoptera: Coccinellidae): Biological aspects and thermal requirements
}

\author{
Tatiana de Oliveira Ramos ${ }^{1^{*}}$, Terezinha Monteiro dos Santos-Cividanes ${ }^{2}$, \\ Francisco Jorge Cividanes $^{1}$, Laís da Conceição dos Santos ${ }^{1}$ \\ ${ }^{1}$ Department of Plant Health, Faculdade de Ciências Agrárias e Veterinárias, Universidade Estadual Paulista, Jaboticabal, Brazil; \\ *Corresponding Author: tatiorbio@gmail.com \\ ${ }^{2}$ Agência Paulista de Tecnologia dos Agronegócios (APTA), Regional Centro Leste, Ribeirão Preto, Brazil
}

Received 17 September 2013; revised 17 October 2013; accepted 8 November 2013

Copyright (C 2014 Tatiana de Oliveira Ramos et al. This is an open access article distributed under the Creative Commons Attribution License, which permits unrestricted use, distribution, and reproduction in any medium, provided the original work is properly cited. In accordance of the Creative Commons Attribution License all Copyrights (C) 2014 are reserved for SCIRP and the owner of the intellectual property Tatiana de Oliveira Ramos et al. All Copyright (C) 2014 are guarded by law and by SCIRP as a guardian.

\section{ABSTRACT}

The aim of this study was to determine the biological aspects and thermal requirements of Harmonia axyridis Pallas (Coleoptera: Coccinellidae) fed daily with Anagasta kuehniella (Zeller) (Lepidoptera: Pyralidae) eggs. Under laboratory conditions, the experiment was carried out in acclimatized chambers set to $18^{\circ} \mathrm{C}, 21^{\circ} \mathrm{C}, 24^{\circ} \mathrm{C}$, $27^{\circ} \mathrm{C}$, and $30^{\circ} \mathrm{C}$. Larvae of $H$. axyridis were separated, kept in a glass tube, and fed with $A$. kuehniella eggs. The Asiatic lady beetle adults were separated into 20 couples and kept in plastic cups receiving the same food as the larvae. The length of the larval, pupal, and total biological cycle (from egg to adult) stages declined significantly from $18^{\circ} \mathrm{C}$ to $27^{\circ} \mathrm{C}$, but was stable between $27^{\circ} \mathrm{C}$ and $30^{\circ} \mathrm{C}$. Survival was similar for larvae from the first to the fourth stadium when kept at $18^{\circ} \mathrm{C}, 21^{\circ} \mathrm{C}$, and $24^{\circ} \mathrm{C}$ with a higher total biological cycle survival at $27^{\circ} \mathrm{C}$. $H$. axyridis males presented higher longevity at $18^{\circ} \mathrm{C}$ and $21^{\circ} \mathrm{C}$ in comparison to females that had a longer life and a higher fecundity at $24^{\circ} \mathrm{C}$ and $27^{\circ} \mathrm{C}$, respectively. The lower thermal limit for biological cycle development was $12.4^{\circ} \mathrm{C}$, and the thermal constant was 243.9 degree-days.

\section{KEYWORDS}

\section{Anagasta kuehniella; Biological Control; Degree-Days}

\section{INTRODUCTION}

Harmonia axyridis Pallas (Coleoptera: Coccinellidae), is found in several countries, in most of which it was introduced as a biological control agent of arthropod pests [1]. In Brazil, the species was initially observed in Curitiba, Paraná, in 2002. Later, it was reported in Ribeirão Preto and Piracicaba, São Paulo in citrus crops and okra and in Viçosa, Minas Gerais, in vegetables. Its distribution is also known to include the states of Rio Grande do Sul, Mato Grosso do Sul, Santa Catarina, and the Federal District [2-5].

The Asian ladybug needs a certain amount of thermal energy to complete its life cycle; in some regions, the length of this variable can be extended for up to 90 days, depending on humidity, photoperiod, and food type [6].

The larval period of the $H$. axyridis was 10.4 days when kept at $25^{\circ} \mathrm{C}$ and fed Myzus persicae (Sulzer) and 17.9 days when fed Cinara atlantica (Wilson). The average life cycle of the species was 14.1 and 12.4 days at $27^{\circ} \mathrm{C}$ when fed Anagasta kuehniella (Zeller) or adults of Schizaphis graminum (Rondani), respectively [7-9]. However, it is unlikely that changes in temperature affect the biological development of $H$. axyridis, because it has successfully reproduced in different climatic conditions [10].

Studies on the thermal requirements of the species enable the forecasting of population growth through the accumulation of temperatures that occur above the minimum developmental temperature [11]. Harmonia axyridis showed similar values for thermal requirements when fed the aphids Dysaphis crataegi (Kaltenbach) and Aphis fabae Scopoli maintained at temperatures of $15^{\circ} \mathrm{C}, 20^{\circ} \mathrm{C}$, $25^{\circ} \mathrm{C}$, and $30^{\circ} \mathrm{C}$ [12].

Only limited information is known about the effect of temperature on $H$. axyridis. Studies related to thermal requirements should be conducted in Brazil to obtain information about the potential of the species as a pest 
control agent. The aim of this study was to determine the biological and thermal requirements of $H$. axyridis fed on eggs of A. kuehniella.

\section{MATERIALS AND METHODS}

The study was developed at the Laboratory of Insect Ecology (LECOL), Department of Plant Health, Universidade Estadual Paulista/Faculdade de Ciências Agrárias e Veterinárias (Unesp/FCAV), Jaboticabal, São Paulo Stade. The third generation of $H$. axyridis eggs used in the experiment was obtained from our own laboratory rearing, kept in a climate-controlled room at $25^{\circ} \mathrm{C} \pm 1^{\circ} \mathrm{C}$ with a 14 -h photophase and relative humidity of $70 \% \pm 5 \%$. The coccinellid species was identified by Dr. Lúcia Massuti de Almeida from the Federal University of Paraná. The experiment began with $100 \mathrm{H}$. axyridis eggs kept in a 6.0 $\mathrm{cm}$ diameter and $2.0 \mathrm{~cm}$ high Petri dish placed in each of the evaluated temperatures of $18^{\circ} \mathrm{C}, 21^{\circ} \mathrm{C}, 24^{\circ} \mathrm{C}, 27^{\circ} \mathrm{C}$, and $30^{\circ} \mathrm{C} \pm 1{ }^{\circ} \mathrm{C}$ with a 14 -h photophase and $70 \% \pm 5 \%$ relative humidity. In sequence, the larvae in the first stadium were separated in glass tubes $(8.0 \mathrm{~cm}$ high $\times 2.5 \mathrm{~cm}$ diameter) and fed A. kuehniella eggs. Twenty-four hours after the stadium change, the larvae were weighed using a precision balance. Daily observations were made to determine the length and survival rate for each larval stadium, pupal phase, and total egg-adult period.

Adults were weighed immediately after emergence and were used to form couples that were kept in $250 \mathrm{~mL}$ transparent plastic cups $(10.0 \mathrm{~cm}$ high $\times 7.0 \mathrm{~cm}$ diameter $)$ sealed with voile cloth. Each couple was fed A. kuehniella eggs ad libitum and observed daily to evaluate the length of the pre-oviposition, oviposition, and post-oviposition periods; daily and total oviposition capability; longevity; and adult survival. The experimental design was completely randomized with 20 replicates held at constant temperatures of $18^{\circ} \mathrm{C}, 21^{\circ} \mathrm{C}, 24^{\circ} \mathrm{C}, 27^{\circ} \mathrm{C}$, and $30^{\circ} \mathrm{C}$. The data were submitted to variance analysis, and the averages were compared with a Tukey test, with significance evaluated at a $5 \%$ probability by using the software AgroEstat and Assistat [13].

The results related to survival were arcsine transformed (P/100)1/2. The $H$. axyridis thermal requirements were determined by the hyperbolic method, by calculate- ing the lower developmental threshold $(\mathrm{Tb})$ (in degrees Celsius) and the thermal constant (K) (in degree-days) by using linear regression between the development time and the corresponding temperatures of $18^{\circ} \mathrm{C}, 21^{\circ} \mathrm{C}, 24^{\circ} \mathrm{C}$, $27^{\circ} \mathrm{C}$, and $30^{\circ} \mathrm{C}$ [14]. The time scale in degree-days was obtained as the daily sum of accumulated degree-days above the lower developmental threshold of $H$. axyridis.

\section{RESULTS AND DISCUSSION}

In general, the duration of the larval period of $H$. axyridis was influenced by temperature, ranging from 2.1 to 5.6 days at temperatures of $30^{\circ} \mathrm{C}$ to $18^{\circ} \mathrm{C}$, respectively (Table 1). The average length of the egg stage at $24^{\circ} \mathrm{C}$ was about 3.3 days, average of 2.8 days for the embryonic period of $H$. axyridis fed on $M$. persicae [8]. The first and second stadium lengths differed significantly among $H$. axyridis raised at $18^{\circ} \mathrm{C}, 21^{\circ} \mathrm{C}$ and $24^{\circ} \mathrm{C}$. However, larvae in the third and fourth stadiums showed a similar development period under $18^{\circ} \mathrm{C}$ and $21^{\circ} \mathrm{C}$, while the development duration was the same at $27^{\circ} \mathrm{C}$ and $30^{\circ} \mathrm{C}$ in all stadiums. The stadium development time at $27^{\circ} \mathrm{C}$ was close to that observed by [9]. They kept $H$. axyridis under the same thermal conditions and recorded 2.5, 1.7, 1.8, and 4.1 days for the length of the first, second, third, and fourth stadiums, respectively, using A. kuehniella eggs as a food source. On the other hand, the fourth stadium larvae had the longest development period. The longer larvae permanence in this stadium is probably related to the higher exploitation of important nutrients. These nutrients are important to transform the pupa into an emerged adult [15]. At $27^{\circ} \mathrm{C}, H$. axyridis completed its larval stage in 9.2 days, which differed from the results obtained by [9]. They found a length of 10.2 days for the species kept at $27^{\circ} \mathrm{C}$ and receiving the same food source.

The average duration of the pupa stage at $27^{\circ} \mathrm{C}$ (Table 1) was similar to the 3.9 days found by research using the aphid S. graminum as food for $H$. axyridis at $27^{\circ} \mathrm{C}$ [9]. In this study, increased temperatures were found to reduce the time of development of the pupal stage. This characteristic is important because it allows one to obtain a larger number of individuals of the species in a smaller period of time under laboratory conditions to be used in

Table 1. Mean duration (days) of the developmental phases of $H$. axyridis fed eggs of A. kuehniella. Temp.: $18^{\circ} \mathrm{C}, 21^{\circ} \mathrm{C}, 24^{\circ} \mathrm{C}, 27^{\circ} \mathrm{C}$, $30^{\circ} \mathrm{C} \pm 1{ }^{\circ} \mathrm{C}$; $\mathrm{RH}: 70 \% \pm 5 \%$; and photophase: $14 \mathrm{~h}$.

\begin{tabular}{|c|c|c|c|c|c|c|c|c|}
\hline $\mathrm{T}\left({ }^{\circ} \mathrm{C}\right)$ & Egg & $1^{\text {st }}$ & $2^{\text {nd }}$ & $3^{\text {rd }}$ & $4^{\text {th }}$ & Larval & Pupal & Egg-adult \\
\hline 18 & ${ }^{\mathrm{a}} 5.6 \pm 0.10 \mathrm{a}$ & $6.5 \pm 0.23 a$ & $4.7 \pm 0.32 \mathrm{a}$ & $4.4 \pm 0.23 a$ & $8.2 \pm 0.31 a$ & $23.8 \pm 0.69 a$ & $10.3 \pm 0.18 a$ & $39.3 \pm 3.7 \mathrm{a}$ \\
\hline 21 & $4.5 \pm 0.10 b$ & $4.5 \pm 0.14 b$ & $3.7 \pm 0.11 b$ & $4.1 \pm 0.12 \mathrm{a}$ & $8.4 \pm 0.17 a$ & $20.7 \pm 0.37 b$ & $7.2 \pm 0.07 b$ & $31.1 \pm 1.5 \mathrm{a}$ \\
\hline 24 & $3.3 \pm 0.07 c$ & $3.5 \pm 0.09 c$ & $2.8 \pm 0.09 c$ & $3.0 \pm 0.10 b$ & $5.3 \pm 0.07 b$ & $14.6 \pm 0.24 c$ & $5.3 \pm 0.06 c$ & $23.1 \pm 1.2 b$ \\
\hline 27 & $2.5 \pm 0.07 d$ & $2.2 \pm 0.07 d$ & $1.4 \pm 0.09 d$ & $1.9 \pm 0.10 c$ & $3.7 \pm 0.11 c$ & $9.2 \pm 0.12 \mathrm{~d}$ & $3.9 \pm 0.06 d$ & $15.9 \pm 0.8 c$ \\
\hline 30 & $2.1 \pm 0.07 e$ & $2.0 \pm 0.03 d$ & $1.3 \pm 0.08 d$ & $1.8 \pm 0.09 c$ & $4.2 \pm 0.10 c$ & $9.3 \pm 0.16 d$ & $4.0 \pm 0.00 \mathrm{~d}$ & $15.2 \pm 0.8 c$ \\
\hline
\end{tabular}

${ }^{a}$ Averages ( \pm deviation) followed by the same letters in columns did not differ by the Tukey test at $5 \%$ probability $(p>0.05)$. 
biological control programs [16].

The biological cycle (egg-adult length) of $H$. axyridis was inversely proportional in the temperatures evaluated. The periods at $18^{\circ} \mathrm{C}$ and $21^{\circ} \mathrm{C}$ were significantly longer than at $24^{\circ} \mathrm{C}, 27^{\circ} \mathrm{C}$, and $30^{\circ} \mathrm{C}$. Research keeping H. axyridis at $25^{\circ} \mathrm{C}$ and using $M$. persicae as food, observed that the species completed its development in 19.8 days, a value greater than the obtained in this research, probably due to nutritional differences in the foods used in the studies [8].

The $H$. axyridis egg viability at $18^{\circ} \mathrm{C}$ and $27^{\circ} \mathrm{C}$ was higher than that at $30^{\circ} \mathrm{C}$, it was lower than that at $21^{\circ} \mathrm{C}$ and $24^{\circ} \mathrm{C}$, but not significantly (Table 2). The survivals of the first and second stadium larvae were similar when they were submitted to different temperatures, while first and fourth stadium larvae presented lower surviving at $30^{\circ} \mathrm{C}$. Value did not differ from the $18^{\circ} \mathrm{C}$ to $24^{\circ} \mathrm{C}$ temperature range but it was higher at $27^{\circ} \mathrm{C}$. This shows that first stadium larvae, which are newly hatched, and fourth stadium larvae, which will become pupae, were more sensitive to temperature than second and third stadium larvae. This may indicate that second and third stadium larvae have a stronger potential to colonize habitats under different climatic conditions.

There were no significant differences in larval survival at different temperatures; however, pupae that had been exposed to $30^{\circ} \mathrm{C}$ had lower adult emergence. The observed survival for the complete biological cycle (egg to adult) of $H$. axyridis was similar at $18^{\circ} \mathrm{C}$ and $24^{\circ} \mathrm{C}$, higher at $27^{\circ} \mathrm{C}$, and lower at $30^{\circ} \mathrm{C}$. Research using the sorghum aphid S. graminum as food had a survival rate of $86.7 \%$ at $24^{\circ} \mathrm{C}$, superior to what was found in this study
[9].

Harmonia axyridis had a shorter biological cycle length (Table 1) and females had a shorter pre-oviposition period at $27^{\circ} \mathrm{C}$ and $30^{\circ} \mathrm{C}$; however, temperatures of $30^{\circ} \mathrm{C}$ had the undesirable effect of reducing the oviposition period (Table 3). An important observation was that the oviposition period was longer at $18^{\circ} \mathrm{C}$ and $24^{\circ} \mathrm{C}$. However, females were more fertile at $27^{\circ} \mathrm{C}$. The reproductive investment in insects is associated with the biologic cycle survival. In this study, the opposite was observed. At $27^{\circ} \mathrm{C}, \mathrm{H}$. axyridis laid a higher number of eggs and had a higher biological cycle survival rate (Table 2) [17].

Even though temperatures of $27^{\circ} \mathrm{C}$ and $30^{\circ} \mathrm{C}$ reduced the development period in the biological cycle (Table 1), under the same thermal conditions, males and females had a shorter lifespan. H. axyridis males had higher longevity at $18^{\circ} \mathrm{C}$ and $21^{\circ} \mathrm{C}$, while females had higher longevity at $18^{\circ} \mathrm{C}$ and $24^{\circ} \mathrm{C}$, surviving for an average of 248.3 days. From $18^{\circ} \mathrm{C}$ to $24^{\circ} \mathrm{C}$, female longevity was 3 times higher than that observed to $H$. axyridis females fed C. atlantica at $24^{\circ} \mathrm{C}$ (85.6 days) [9]. The authors highlighted that coccinellidae longevity is highly variable, ranging from a few months up to 3 years.

The temperature also influences the development time of insects, which affects the weight of larvae [1]. In general, $H$. axyridis larvae in the second, third, and fourth instars had higher weights at $27^{\circ} \mathrm{C}$, while adults had similar weights at all temperatures (Table 4). The weights of $H$. axyridis larvae and adults at $30^{\circ} \mathrm{C}$ were not included because there was low survival in this treatment. At all temperatures, the weight increased with each stadium change up to the adult phase [18].

Table 2. Mean survival (\%) for larvae, pupae, and the total biological cycle and egg viability of H. axyridis fed A. kuehniella. Temp.: $18^{\circ} \mathrm{C}, 21^{\circ} \mathrm{C}, 24^{\circ} \mathrm{C}, 27^{\circ} \mathrm{C}, 30^{\circ} \mathrm{C} \pm 27^{\circ} \mathrm{C}, 30^{\circ} \mathrm{C} \pm 1^{\circ} \mathrm{C}$; RH: $70 \% \pm 5 \%$; and photophase: $14 \mathrm{~h}$.

\begin{tabular}{|c|c|c|c|c|c|c|c|c|}
\hline $\mathrm{T}\left({ }^{\circ} \mathrm{C}\right)$ & Egg & $1^{\text {st }}$ & $2^{\text {nd }}$ & $3^{\text {rd }}$ & $4^{\text {th }}$ & Larval & Pupal & Egg-Adult \\
\hline 18 & a $82.0 \pm 3.8 \mathrm{a}$ & $89.0 \pm 3.4 \mathrm{bc}$ & $98.0 \pm 2.0 \mathrm{a}$ & $99.0 \pm 1.0 \mathrm{a}$ & $71.0 \pm 3.9 \mathrm{bc}$ & $72.6 \pm 18.9 b$ & $70.0 \pm 3.6 \mathrm{bc}$ & $61.2 \pm 4.1 \mathrm{ab}$ \\
\hline 21 & $68.7 \pm 6.8 \mathrm{ab}$ & $86.9 \pm 5.8 b c$ & $100.0 \pm 0.0 \mathrm{a}$ & $100.0 \pm 0.0 \mathrm{a}$ & $58.7 \pm 7.1 \mathrm{bc}$ & $76.2 \pm 32.0 \mathrm{~b}$ & $58.7 \pm 7.1 \mathrm{bc}$ & $43.0 \pm 6.6 \mathrm{bc}$ \\
\hline 24 & $74.7 \pm 6.8 \mathrm{ab}$ & $90.5 \pm 4.4 \mathrm{bc}$ & $100.0 \pm 0.0 \mathrm{a}$ & $98.6 \pm 1.3 \mathrm{a}$ & $64.2 \pm 6.2 \mathrm{bc}$ & $86.5 \pm 22.2 \mathrm{a}$ & $64.2 \pm 6.2 \mathrm{bc}$ & $52.3 \pm 3.4 \mathrm{ab}$ \\
\hline 27 & $83.0 \pm 4.1 \mathrm{a}$ & $94.5 \pm 2.2 \mathrm{a}$ & $98.7 \pm 1.2 \mathrm{a}$ & $97.3 \pm 1.9 \mathrm{a}$ & $77.0 \pm 3.9 \mathrm{a}$ & $76.7 \pm 20.7 b$ & $76.0 \pm 4.0 \mathrm{a}$ & $63.7 \pm 3.4 \mathrm{a}$ \\
\hline 30 & $65.0 \pm 8.2 b$ & $72.7 \pm 7.8 \mathrm{c}$ & $100.0 \pm 0.0 \mathrm{a}$ & $100.0 \pm 0.0 \mathrm{a}$ & $46.6 \pm 7.1 c$ & $58.2 \pm 27.4 \mathrm{c}$ & $46.6 \pm 7.1 \mathrm{c}$ & $28.1 \pm 7.0 \mathrm{c}$ \\
\hline
\end{tabular}

${ }^{a}$ Averages ( \pm deviation) followed by the same letters in columns did not differ by the Tukey test at $5 \%$ probability $(p>0.01)$. At each temperature (treatment), there were 100 eggs. Survival data were transformed by arcsine $(\mathrm{P} / 100)^{1 / 2}$.

Table 3. Mean duration (days) of the pre-oviposition, oviposition, and post-oviposition periods and longevity (days) of $H$. axyridis fed A. kuehniella. Temp.: $18^{\circ} \mathrm{C}, 21^{\circ} \mathrm{C}, 24^{\circ} \mathrm{C}, 27^{\circ} \mathrm{C}, 30^{\circ} \mathrm{C} \pm 1^{\circ} \mathrm{C}$; $\mathrm{RH}$ : $70 \% \pm 5 \%$; and photophase: $14 \mathrm{~h}$.

\begin{tabular}{cccccccc}
\hline $\mathrm{T}\left({ }^{\circ} \mathrm{C}\right)$ & Pre-oviposition & Oviposition period & Post-oviposition & Total eggs & Daily eggs & Longevity (Male) & Longevity (Female) \\
\hline 18 & ${ }^{\mathrm{a}} 88.7 \pm 15.6 \mathrm{ab}$ & $158.4 \pm 18.4 \mathrm{a}$ & $13.8 \pm 2.2 \mathrm{ab}$ & $806.0 \pm 78.4 \mathrm{c}$ & $8.0 \pm 1.2 \mathrm{~b}$ & $221.7 \pm 11.7 \mathrm{a}$ & $242.2 \pm 16.9 \mathrm{a}$ \\
21 & $116.7 \pm 7.9 \mathrm{a}$ & $117.1 \pm 7.4 \mathrm{ab}$ & $24.9 \pm 3.6 \mathrm{a}$ & $967.9 \pm 102.9 \mathrm{c}$ & $8.8 \pm 0.9 \mathrm{~b}$ & $185.0 \pm 10.6 \mathrm{ab}$ & $244.9 \pm 13.2 \mathrm{a}$ \\
24 & $74.0 \pm 7.5 \mathrm{~b}$ & $157.9 \pm 11.6 \mathrm{a}$ & $14.2 \pm 3.5 \mathrm{ab}$ & $1.430 .2 \pm 194.1 \mathrm{bc}$ & $8.5 \pm 0.9 \mathrm{~b}$ & $200.7 \pm 9.8 \mathrm{a}$ & $259.4 \pm 10.1 \mathrm{a}$ \\
27 & $11.7 \pm 1.0 \mathrm{c}$ & $143.4 \pm 12.3 \mathrm{ab}$ & $11.5 \pm 1.06 \mathrm{~b}$ & $2.642 .4 \pm 210.7 \mathrm{a}$ & $21.2 \pm 2.0 \mathrm{a}$ & $103.1 \pm 10.1 \mathrm{~b}$ & $154.7 \pm 10.1 \mathrm{~b}$ \\
30 & $14.3 \pm 1.3 \mathrm{c}$ & $96.4 \pm 6.8 \mathrm{~b}$ & $14.3 \pm 2.8 \mathrm{ab}$ & $1.685 .2 \pm 209.6 \mathrm{~b}$ & $18.0 \pm 1.9 \mathrm{a}$ & $115.4 \pm 8.3 \mathrm{~b}$ & $140.6 \pm 7.01 \mathrm{~b}$ \\
\hline
\end{tabular}

${ }^{a}$ Averages ( \pm deviation) followed by the same letters in columns did not differ by the Tukey test at $5 \%$ probability. 
Table 4. Mean weights (mg) of the second, third, and fourth stadium larvae and adults of $H$. axyridis fed A. kuehniella. Temp.: $18^{\circ} \mathrm{C} 21^{\circ} \mathrm{C}, 24^{\circ} \mathrm{C}, 27^{\circ} \mathrm{C} \pm 1{ }^{\circ} \mathrm{C}$; $\mathrm{RH}: 70 \% \pm 5 \%$; and photophase: $14 \mathrm{~h}$.

\begin{tabular}{ccccc}
\hline $\mathrm{T}\left({ }^{\circ} \mathrm{C}\right)$ & $2^{\text {nd }}$ stadium & $3^{\text {rd }}$ stadium & $4^{\text {th }}$ stadium & Adult \\
\hline 18 & ${ }^{\mathrm{a}} 1.5 \pm 0.10 \mathrm{c}$ & $5.3 \pm 0.44 \mathrm{~b}$ & $16.2 \pm 2.3 \mathrm{bc}$ & $23.8 \pm 1.5 \mathrm{a}$ \\
21 & $1.8 \pm 0.13 \mathrm{bc}$ & $5.0 \pm 0.37 \mathrm{~b}$ & $12.0 \pm 0.71 \mathrm{c}$ & $24.8 \pm 1.2 \mathrm{a}$ \\
24 & $2.0 \pm 0.14 \mathrm{~b}$ & $7.2 \pm 0.46 \mathrm{a}$ & $20.1 \pm 1.6 \mathrm{~b}$ & $27.6 \pm 1.2 \mathrm{a}$ \\
27 & $2.8 \pm 0.08 \mathrm{a}$ & $8.4 \pm 0.15 \mathrm{a}$ & $26.1 \pm 1.6 \mathrm{a}$ & $29.6 \pm 2.5 \mathrm{a}$ \\
\hline
\end{tabular}

${ }^{a}$ Averages ( \pm deviation) followed by the same letters in columns did not differ by the Tukey test at $5 \%$ probability. Data represent the average of 15 replications \pm deviation. The weights of coccinellidae kept at $30^{\circ} \mathrm{C}$ were not included in the calculations

The $H$. axyridis fourth stadium, pupal period, and biologic cycle development length values at $30^{\circ} \mathrm{C}$ were not included in calculating the thermal demand because, under this temperature, the development time was longer, differing from the other observations of the relationship between the development rate and other temperatures. It has been recommended that development velocity values be rejected when there is not a linear relationship between values [19].

The values of eggs and the total biological cycle (Table 5) determined in our study are close to those determined for the coccinellidae Coleomegilla maculata (DeGeer) and Chilocorus bipustulatus Linnaeus with values for $\mathrm{Tb}$ and $\mathrm{K}$ for the egg stage at $11.0^{\circ} \mathrm{C}$ and $11.3^{\circ} \mathrm{C}$ and from 40.2 to 123.6 degree-days and for the biological cycle values varying from $11.3^{\circ} \mathrm{C}$ to $11.4^{\circ} \mathrm{C}$ and 101.0 to 235.8 degree-days [20,21]. However, the $\mathrm{Tb}$ and $\mathrm{K}$ obtained for $H$. axyridis in this study differed from other values for $H$. axyridis in France $(\mathrm{Tb}=$ $10.5^{\circ} \mathrm{C}$ and $\mathrm{K}=231.3$ degree-days), in the United States ( $\mathrm{Tb}=11.2^{\circ} \mathrm{C}$ and $\mathrm{K}=267.3$ degree-days), and in Denmark $\left(\mathrm{Tb}=10.5^{\circ} \mathrm{C}\right.$ and $\mathrm{K}=231.0$ degree-days) $[1,5$, $6,8-10,12,17,18,21,22]$. As explained before, this difference among $\mathrm{Tb}$ and $\mathrm{K}$ values might be explained by the foods used and by the different biotypes existing in the regions where the studies were carried out, considering that the climatic conditions of a region are reflected in the insects thermal requirement values [1, $4-10,12,14,17-22]$. The results of this study show that the temperature of $27^{\circ} \mathrm{C}$ is more favorable to $H$. axyridis, providing a faster development and a higher fecundity. $H$. axyridis has favorable development at different temperatures when fed on A. kuehniella eggs. The temperature of $30^{\circ} \mathrm{C}$ lengthens the development time for the larval and pupal stages and reduces survival by up to $54 \%$. The low development thermal limit values as well as the biologic cycle thermal constant suggest that $H$. axyridis should be able to develop and establish itself in different regions of Brazil.
Table 5. Lower developmental thermal limit (Tb), thermal constant $(\mathrm{K})$, and determination coefficient $\left(\mathrm{R}^{2}\right)$ for the different developmental stages and the total biological cycle of $H$. axyridis fed A. kuehniella. Temp.: $18^{\circ} \mathrm{C}, 21^{\circ} \mathrm{C}, 24^{\circ} \mathrm{C}, 27^{\circ} \mathrm{C}$, $30^{\circ} \mathrm{C} \pm 1{ }^{\circ} \mathrm{C}$; $\mathrm{RH}: 70 \% \pm 5 \%$; and photophase: $14 \mathrm{~h}$.

\begin{tabular}{ccccc}
\hline Phase & $\mathrm{Tb}\left({ }^{\circ} \mathrm{C}\right)$ & ${ }^{\mathrm{a}} \mathrm{K}(\mathrm{GD})$ & ${ }^{\mathrm{b}}$ Equation $(1 / \mathrm{D})$ & $\mathrm{R}^{2}$ \\
\hline Egg & 11.3 & 40.7 & $\mathrm{Y}=-0.279756+0.02455 \mathrm{x}$ & 99.3 \\
$1^{\text {st }}$ instar & 13.2 & 33.6 & $\mathrm{Y}=-0.395167+0.02972 \mathrm{x}$ & 97.9 \\
$2^{\text {nd }}$ instar & 14.5 & 19.9 & $\mathrm{Y}=-0.728590+0.05006 \mathrm{x}$ & 93.9 \\
$3^{\text {rd }}$ instar & 10.9 & 34.8 & $\mathrm{Y}=-0.314516+0.02828 \mathrm{x}$ & 90.5 \\
$4^{\text {th }}$ instar & 11.4 & 63.8 & $\mathrm{Y}=-0.179831+0.01565 \mathrm{x}$ & 90.0 \\
Larva & 12.0 & 156.4 & $\mathrm{Y}=-0.077115+0.00639 \mathrm{x}$ & 93.2 \\
Pupa & 12.8 & 55.9 & $\mathrm{Y}=-0.230340+0.01788 \mathrm{x}$ & 98.0 \\
Egg-adult & 12.4 & 243.9 & $\mathrm{Y}=-0.000511+0.00410 \mathrm{x}$ & 93.0 \\
\hline
\end{tabular}

${ }^{\mathrm{a} D D}$ : degree-days; ${ }^{\mathrm{b}} 1 / \mathrm{D}$ : development speed equation; D: development length (days).

\section{ACKNOWLEDGEMENTS}

The authors thank the Foundation for Research Support of the State of São Paulo (FAPESP) for the financial support to develop the research and to National Council for Scientific and Technological Development $(\mathrm{CNPq})$ for the scholarship to the first author.

\section{REFERENCES}

[1] Koch, R.L. (2003) The multicolored Asian lady beetle, Harmonia axyridis: A review of its biology, uses in biological control, and non-target impacts. Journal of Insect Science, 3, 1-16.

[2] Almeida, L.M. and Silva, V.B. (2002) First record of Harmonia axyridis (Pallas) (Coleoptera, Coccinellidae): A lady beetle native to the Palaeartic region. Revista Brasileira de Zoologia, 19, 941-944. http://dx.doi.org/10.1590/S0101-81752002000300031

[3] Arruda Filho, G.P., Berti Filho, E. and Pereira, R.A. (2009) Occurrence of Harmonia axyridis (Coleoptera: Coccinellidae) in the state of São Paulo, Brazil. Revista de Agricultura, 84, 145-148.

[4] Koch, R.L., Fernandes, M.G. and Dutra, C.C. (2011) First confirmed record of Harmonia axyridis (Pallas, 1773) (Coleoptera: Coccinellidae) in the state of Mato Grosso do Sul, Brasil. Journal of Species List and Distribution, 7, 476-477.

[5] Santos-Cividanes, T.M., Cividanes, F.J., Ribeiro, A.A. and Leite, M.V. (2010) Diversity of Coccinellidae in the culture of okra in Ribeirão-Preto, SP. Pesquisa \& Tecnologia, 7, 26.

[6] Soares, A.O., Coderre, D. and Schanderl, H. (2004) Dietary self-selection behavior by the adults of the aphidophagous ladybeetle Harmonia axyridis (Coleoptera, Coccinellidae). Journal of Animal Ecology, 73, 478-486. http://dx.doi.org/10.1111/j.0021-8790.2004.00822.x

[7] Castro, C.F., Almeida, L.M. and Penteado, S.R.C. (2011) The impact of temperature on biological aspects and life table of Harmonia axyridis (Pallas) (Coleoptera: Coccinellidae). Florida Entomologist, 94, 923-932. 
http://dx.doi.org/10.1653/024.094.0429

[8] Lanzoni, A., Accinelli, G., Bazzocchi, G.G. and Burgio, G. (2004) Biological traits and life table of the exotic Harmonia axyridis compared with Hippodamia variegate and Adalia bipunctata (Coleoptera: Coccinellidae). Journal of Applied Entomology, 128, 298-306.

[9] Santos, N.R.P., Santos-Cividanes, T.M., Matos, B.A. and Anjos, A.C.R. (2009) Biological aspects Harmonia axyridis fed with two prey and intraguild predation with Eriopis connexa. Pesquisa Agropecuária Brasileira, 44, 554-560. http://dx.doi.org/10.1590/S0100-204X2009000600002

[10] Majerus, M., Strawson, V. and Roy, H. (2006) The potential impacts of the arrival of the harlequin ladybird Harmonia axyridis (Pallas) (Coleoptera: Coccinellidae), in Britain. Ecological Entomology, 31, 207-215. http://dx.doi.org/10.1111/j.1365-2311.2006.00734.x

[11] Wilson, L.T. and Barnett, W.W. (1983) Degree-days: An aid in crop and pest management. California Agriculture, 37, 4-7.

[12] Stathas, G.J., Kontodimas, D.C., Karamaouna, F. and Kampouris, S. (2011) Thermal requirements and effect of temperature and prey on the development of the predator Harmonia axyridis. Entomological Society of America, 6, 1541-1545.

[13] Barbosa, J.C. and Maldonato Júnior, W. (2010) AgroEstat: System for statistical analysis of agronomic trials. Jaboticabal: FCAV/UNESP.

[14] Haddad, M.L., Parra, J.R.P. and Moraes, R.C.B. (1999) Methods for estimating the lower and upper thermal limits of development of insects. FEALQ, Piracicaba.

[15] Veloso, V.R.S., Naves, V.R., Nascimento, J.R., Fernandes,
P.M. and Garcia, A.H. (1995) Biological aspects of Cycloneda sanguinea (L.) (Coleoptera: Coccinellidae). Anais da Escola de Agronomia e Veterinária, 25, 123-127.

[16] Auad, A.M. (2003) Biological aspects of the immature stages of Pseudodorus clavatus (Fabricius) (Diptera: Syrphidae) fed Schizaphis graminun (Rondani) (Hemiptera: Aphididae) at different temperatures. Neotropical Entomolgy, 32, 475-480.

http://dx.doi.org/10.1590/S1519-566X2003000300015

[17] Ricklefs, R.E. (2003) The economy of nature. Guanabara Koogan, Rio de Janeiro.

[18] Parra, J.R.P. (1999) Techniques of insect rearing for biological control. ESALQ/FEALQ, Piracicaba.

[19] Campbell, A., Frazer, B.D., Gilbert, N., Gutierrez, A.P. and Mackauer, M. (1974) Temperature requirements of some aphids and their parasites. The Journal of Apllied Ecology, 11, 431-438. http://dx.doi.org/10.2307/2402197

[20] Eliopoulos, P.A., Kontodimas, D.C. and Stathas, G.J. (2010) Temperature-dependent development of Chilocorus bipustulatus (Coleoptera: Coccinellidae). Entomological Society of America, 39, 1352-1358. http://dx.doi.org/10.1603/EN09364

[21] Obrychi, J.J. and Tauber, M.J. (1978) Thermal requirements for development of Coleomegilla maculata (Coleoptera: Coccinellidae) and its parasite Perilitus coccinellae (Hymenoptera: Braconidae). Canadian Entomologist, 10, 407-412. http://dx.doi.org/10.4039/Ent110407-4

[22] Steenberg, T. and Harding, S. (2009) The harlequin ladybird Harmonia axyridis (Pallas) in Denmark: Spread and phenology during the initial phase of invasion. Entomologiske Meddelelser, 1, 27-39. 